\title{
Habitat use by the endangered white-clawed crayfish Austropotamobius species complex: a systematic review
}

\author{
Paula J. Rosewarne ${ }^{1}$, Robert J.G. Mortimer ${ }^{2}$ and Alison M. Dunn ${ }^{1, *}$ \\ ${ }^{1}$ School of Biology, Faculty of Biological Sciences, University of Leeds, Leeds LS2 9JT, UK \\ 2 School of Animal, Rural and Environmental Sciences, Nottingham Trent University, Brackenhurst Campus, Southwell, Nottinghamshire \\ NG25 0QF, UK
}

\begin{abstract}
Understanding habitat requirements is a key part of conserving declining species, particularly when reintroductions are planned as part of the recovery strategy. The white-clawed crayfish (Austropotamobius pallipes) has undergone severe declines across its range and is now classified by the International Union for Conservation of Nature (IUCN) as 'endangered'. Translocation of threatened $A$. pallipes populations to isolated 'Ark sites' where threats are minimised is an increasingly used conservation tool. A full feasibility assessment of potential Ark sites, including an assessment of habitat suitability, is recommended within translocation guidelines developed by the IUCN. This literature review employed a systematic search and 'vote counting' approach to identify and assess the relative importance of physical habitat requirements of $A$. pallipes. Many habitat features were positively associated with crayfish presence, in particular: boulder substrate, trees/shading, woody debris, exposed roots, and undercut banks; and habitat use patterns varied among crayfish sexes and size classes. Ark sites should incorporate heterogeneous habitat, with as many of these features as possible, to provide both ample refugia and rich foraging areas.
\end{abstract}

Keywords: freshwater / habitat suitability / translocation / conservation / aquatic invertebrate

\begin{abstract}
Résumé - Utilisation de l'habitat par le complexe d'espèces d'Austropotamobius, écrevisses à pieds blancs menacées : revue systématique. La compréhension des besoins en matière d'habitat est un élément clé de la conservation des espèces en déclin, en particulier lorsque des réintroductions sont prévues dans le cadre de la stratégie de restauration. L'écrevisse à pieds blancs (Austropotamobius pallipes) a subi de graves déclins dans toute son aire de répartition et est maintenant classée en « espèce en danger ». La translocation des populations d'A. pallipes menacées vers des «sites Ark» isolés où les menaces sont minimisées est un outil de conservation de plus en plus utilisé. Une évaluation complète de la faisabilité des sites 'Ark' potentiels, y compris une évaluation de l'aptitude des habitats, est recommandée dans les lignes directrices sur la translocation élaborées par l'UICN. Cette revue de littérature a fait appel à une recherche systématique et à une méthode de 'vote counting' pour identifier et évaluer l'importance relative des besoins en matière d'habitat physique d'A. pallipes. De nombreuses caractéristiques de l'habitat ont été positivement associées à la présence d'écrevisses, notamment : substrat de blocs, arbres / ombrage, débris ligneux, racines exposées et berges surplombantes; et les habitudes d'utilisation de l'habitat varient selon les sexes et les classes de taille des écrevisses. Les sites Ark devraient intégrer un habitat hétérogène, avec autant de ces caractéristiques que possible, pour fournir à la fois suffisamment de refuges et de riches zones de ravitaillement.
\end{abstract}

Mots clés : eau douce / habitat adéquat / translocation / préservation / invertébré aquatique

\section{Introduction}

Range reduction of the white-clawed crayfish (Austropotamobius pallipes), one of only five crayfish species indigenous to Europe began as early as the 1860s (SoutyGrosset et al., 2006), although declines rapidly accelerated

* Corresponding author: a. dunn@leeds.ac.uk following introduction of invasive non-indigenous crayfish species, such as Pacifastacus leniusculus and Procambarus clarkii from North America in the 1970s (Holdich and Gherardi, 1999; Gil-Sanchez and Alba-Tercedor, 2002). The spread of crayfish plague Aphanomyces astaci, an oomycete pathogen carried by North American crayfish, but fatal to European crayfish, has had the greatest impact on populations (Alderman et al., 1990; Holdich, 2003a); although pollution 
(Fureder and Reynolds, 2003) and habitat modification (Hogger, 1986), loss and degradation (Holdich and Reeve, 1991) have all been implicated in the decline. Despite legislative protection at the European scale, with A. pallipes listed under annexes II and V of the EU Habitats Directive (92/43/EEC) and Appendix II of the Bern Convention, it has declined in Europe by $50-80 \%$ over the last decade (SoutyGrosset and Reynolds, 2009).

While a widely applicable and cost-effective means to control invasive crayfish remains elusive, translocation of threatened populations has become a key component of crayfish conservation strategy in Europe (Schulz et al., 2002). In addition to restocking areas of dwindling population and reintroduction of $A$. pallipes to watercourses where it has been extirpated, introductions to isolated still waters free from invasive crayfish and aptly named 'Ark sites' are widely being carried out (Holdich et al., 2004; Souty-Grosset and Reynolds, 2009). With a significantly lower invasion threat, these off-line water bodies are hoped to provide long-term strongholds for native populations in invaded catchments, and ultimately restocking material if invader-free watercourses can be secured in the future (Schulz et al., 2002).

Understanding habitat requirements is fundamental for the conservation of declining species generally, but particularly when reintroductions are planned as part of the recovery strategy (Seddon et al., 2007; Sutherland, 2008). The IUCN highlights that habitat assessment of the recipient site as a key stage in the process of conservation translocation (IUCN, 2012), however some argue that this is rarely carried out to an adequate level (Osborne and Seddon, 2012). In an analysis of A. pallipes reintroductions in Europe, $44 \%$ (26 out of 59) were deemed successful, with the authors highlighting that suitability of target habitat, along with selection of stocking material and appropriate stocking procedures, is paramount to translocation success (Souty-Grosset and Reynolds, 2009). In the UK's best practice guidelines for such translocations, suitable habitat is highlighted as a key criterion in the selection of recipient Ark sites (Kemp et al., 2003; Peay, 2009). Largescale GIS-mapping and interrogation of variables, including habitat parameters, on a national or regional scale is advocated as a valuable starting point in the identification of possible recipient sites (Kindemba and Whitehouse, 2009). Once potential sites have been identified, more detailed assessment of habitat against pre-defined criteria compiled using expert opinion, against which the site is subjectively rated on a scale of 1-4 based on the description of a range of habitat variables, should occur (Buglife, 2009).

Within translocation guidelines, the habitat features considered important for $A$. pallipes may be broadly summarised as suitable water chemistry, stable flow regimes, ample physical habitat structure to provide refugia, presence of instream vegetation and low pollution/disturbance risk (Kemp et al., 2003). There have been several reviews of the literature, including a general review of the habitat factors affecting cool water crayfish species by Lodge and Hill (1994), which dealt mainly with species of commercial importance such as Orconectes or Astacus spp., though did identify a preference of $A$. pallipes for rocky, lotic environments. Within another review based on four studies, Holdich and Rogers (2000) compiled a broad list of attributes deemed to denote desirable habitat for the species, however the authors note that
A. pallipes does occur in locations where many of those habitat attributes are not present. Conversely, it is often absent from watercourses where conditions appear optimal, with no previous pollution or invasive crayfish, and no apparent dispersal limitations (Nardi et al., 2005). Recent quantitative reviews have focussed solely on water quality, identifying tolerance thresholds of $A$. pallipes for the main water chemistry parameters (Trouilhe et al., 2007; Haddaway et al., 2015).

Concurrent with increasing recognition of the plight of the endangered white-clawed crayfish and of the many knowledge gaps concerning this species, much work has been carried out over the last 15 years. Habitat has been one research focus, addressing species distribution patterns and habitat use at a range of temporal and spatial scales. Novel approaches and advancements in technology (e.g. radio telemetry) have for the first time enabled study at the microhabitat level in the wild, revealing much about the resource use and spatial ecology of $A$. pallipes. In recognition of recent advancements, we conducted a systematic review with the aim to collate and synthesise published work relating to $A$. pallipes and physical habitat. Extracted data were explored for patterns of presence/ absence and microhabitat use with respect to a series of habitat variables including channel substrate, vegetation and hydrodynamic parameters.

\section{Materials and methods}

Literature searches were carried out using Web of Knowledge and Google Scholar to retrieve studies that reported habitat use or associations for genus Austropotamobius. The following search string was used: 'Austropotamobius AND (habitat OR microhabitat OR distribution)' and searches were performed 12th November 2010 and updated 19th November 2015 to include studies published in the interim. All records returned from Web of Knowledge were exported to reference management software (Endnote X2). Despite the large number of hits returned by Google Scholar, pilot searches showed that relevance declined rapidly after the initial 60 or so records, therefore only the first 140 records were exported. Duplicate articles were subsequently eliminated and the remainder underwent screening using predefined retention criteria (Tab. 1). The selection criteria were designed to retain only those articles that were relevant to the aims of this review, i.e., that quantitatively assessed the relationship between crayfish occurrence/density and habitat variables. Studies that focussed solely on water chemistry parameters were excluded because these have been reviewed quantitatively elsewhere (Trouilhe et al., 2007; Haddaway et al., 2015).

The taxonomy of $A$. pallipes and $A$. italicus is controversial. The historic classification as two distinct species based on 16S rRNA (Grandjean and Souty-Grosset, 2000; Grandjean et al., 2002; Fratini et al., 2005) has recently been robustly challenged by a combined analyses of CO-I gene fragments and AFLP fingerprinting which indicated that $A$. pallipes and $A$. italicus are one species (Chiesa et al., 2011). Therefore, studies addressing both $A$. pallipes and $A$. italicus are included in this study. Studies addressing solely the stone crayfish (Austropotamobius torrentium) were excluded because 
although $A$. torrentium is closely related to $A$. pallipes, it occupies a different European range extending from Germany in the west to Turkey in the east (Machino and Füreder, 2005). In contrast to $A$. pallipes which inhabits both large and small lotic and lentic water bodies across a wide range of altitudes, $A$. torrentium is generally found in circum-alpine habitats and small streams (Huber and Schubart, 2005).

The papers retained after screening were interrogated to extract data and populate a database. The fields of enquiry included: (1) species of interest; (2) location; (3) number of catchments, watercourses and sites studied; (4) crayfish sampling method; (5) crayfish sampling time, i.e., day or night; (6) habitat variables measured, and (7) presence and direction of any quantitative relationships identified statistically between crayfish occurrence/density and each measured habitat variable.

\section{Results}

A total of 324 unique records were retrieved from the searches and 20 met the selection criteria (Tab. 1) and were retained for full review. The reviewed studies were published from 1995 to 2014 and originated from Italy (40\%), UK $(30 \%)$, Spain (15\%), France $(10 \%)$ and Ireland $(5 \%)$. Studies pre-dating 1995 were retrieved by the searches, but were excluded on the basis that they did not statistically test quantitative relationships between $A$. pallipes and habitat variables. The majority of studies (85\%) addressed solely lotic systems. Sixty-five percent of studies were conducted at the 'catchment-scale', i.e., investigated crayfish distribution among sites on multiple watercourses, whereas $35 \%$ were 'reach-scale', i.e., addressed just one watercourse. Catchment-scale studies predominantly used presence-absence crayfish data derived from hand-search during the day, night viewing and trapping (Tab. 2). No studies at the reach-scale used presence-absence data; instead they investigated crayfish abundance or finer scale movement patterns derived from similar methods, with the addition of radio-tracking and Surber sampling (Tab. 3).

Data regarding 19 habitat variables were extracted from the studies where available (Tabs. 2 and 3). The abundance and diversity of macro-invertebrate communities was also investigated in six studies and although not a physical habitat feature, was included for completeness. Eighteen of the habitat variables investigated showed association with crayfish at the catchment-scale compared to 12 at the reach-scale (Figs. 1 and 2), with much variation in the relative importance of variables and direction of relationships among the two categories.

At the catchment scale, the highest proportion of significant relationships were found for boulders/cobbles, trees/ shading, in-stream vegetation and bank structure, which were all generally positively associated with crayfish present and/or abundance (Fig. 1). At the reach-scale, channel substrate parameters were the most commonly investigated and a similar generally positive association was found for boulders/cobbles, however woody debris/roots, flow type and bank structure were most significant with relationships reported in $100 \%$ of studies in which these variables were measured (Fig. 2).
Table 1. Predefined inclusion criteria for literature returned by systematic search.

\begin{tabular}{|c|c|}
\hline Criterion & $\begin{array}{l}\text { Priority within } \\
\text { screening process }\end{array}$ \\
\hline $\begin{array}{l}\text { Considers Austropotamobius } \\
\text { pallipes or A. italicus }\end{array}$ & 1 \\
\hline $\begin{array}{l}\text { Empirically and quantitatively } \\
\text { assesses relationship between } \\
\text { habitat features and crayfish } \\
\text { occurrence in the wild. Some } \\
\text { aspect of physical habitat } \\
\text { structure must be addressed; not } \\
\text { solely water chemistry data. }\end{array}$ & 2 \\
\hline $\begin{array}{l}\text { Where a study had multiple } \\
\text { aims, only data relating directly } \\
\text { to habitat-use were considered. }\end{array}$ & \\
\hline $\begin{array}{l}\text { Is primary literature published } \\
\text { in peer reviewed journals, or } \\
\text { conference proceedings }\end{array}$ & 3 \\
\hline Full text available in English & 4 \\
\hline
\end{tabular}

\section{Discussion}

\subsection{Channel substrate}

The importance of channel substrate varied with particle size. The coverage of boulders and pebbles was most important at both the catchment and reach scales $(50 \%$ and $20 \%$, and $57 \%$ and $17 \%$ of potential associations found to be significant, respectively). Generally, a positive relationship was found between the occurrence of crayfish and prevalence of boulder substrates, however Brusconi et al. (2008) identified varying relationships based on size classes whereby juvenile crayfish preferentially selected cobbles, though adults tended to avoid them. Naura and Robinson (1998) differentiated between boulders and cobbles and found a positive relationship with regards boulders, but a negative one for cobbles. Larger rocks such as boulders and cobbles provide refugia as crayfish hide underneath them; the largest and flattest rocks representing the most desirable dimensions (Watson and Rogers, 2003). Predation, and to a lesser extent cannibalism, cause crayfish to seek shelter in refugia during inactive daylight hours (Barbaresi and Gherardi, 2001). Indeed, disputes over shelter are one of the main reasons for agonistic interactions (Gherardi et al., 2002; Gherardi and Cioni, 2004), and the availability of such refugia is a strong limiting factor to crayfish numbers (Lodge and Hill, 1994; Holdich, 2003b) and growth rates (Olsson and Nystrom, 2009). Refugia also provide protection against strong currents during flood periods (i.e., downstream drift) with boulders representing a more valuable resource in this regard than smaller cobbles and pebbles (Streissl and Hödl, 2002).

One study showed equal association of crayfish with finer substrates such as pebbles, gravel and sand (Barbaresi et al., 2007), and another inferred that crayfish actually avoided cobble and boulder substrates, positively selecting fine substrate and more exposed microhabitats (Clavero et al., 
P.J. Rosewarne et al.: Knowl. Manag. Aquat. Ecosyst. 2017, 418, 4

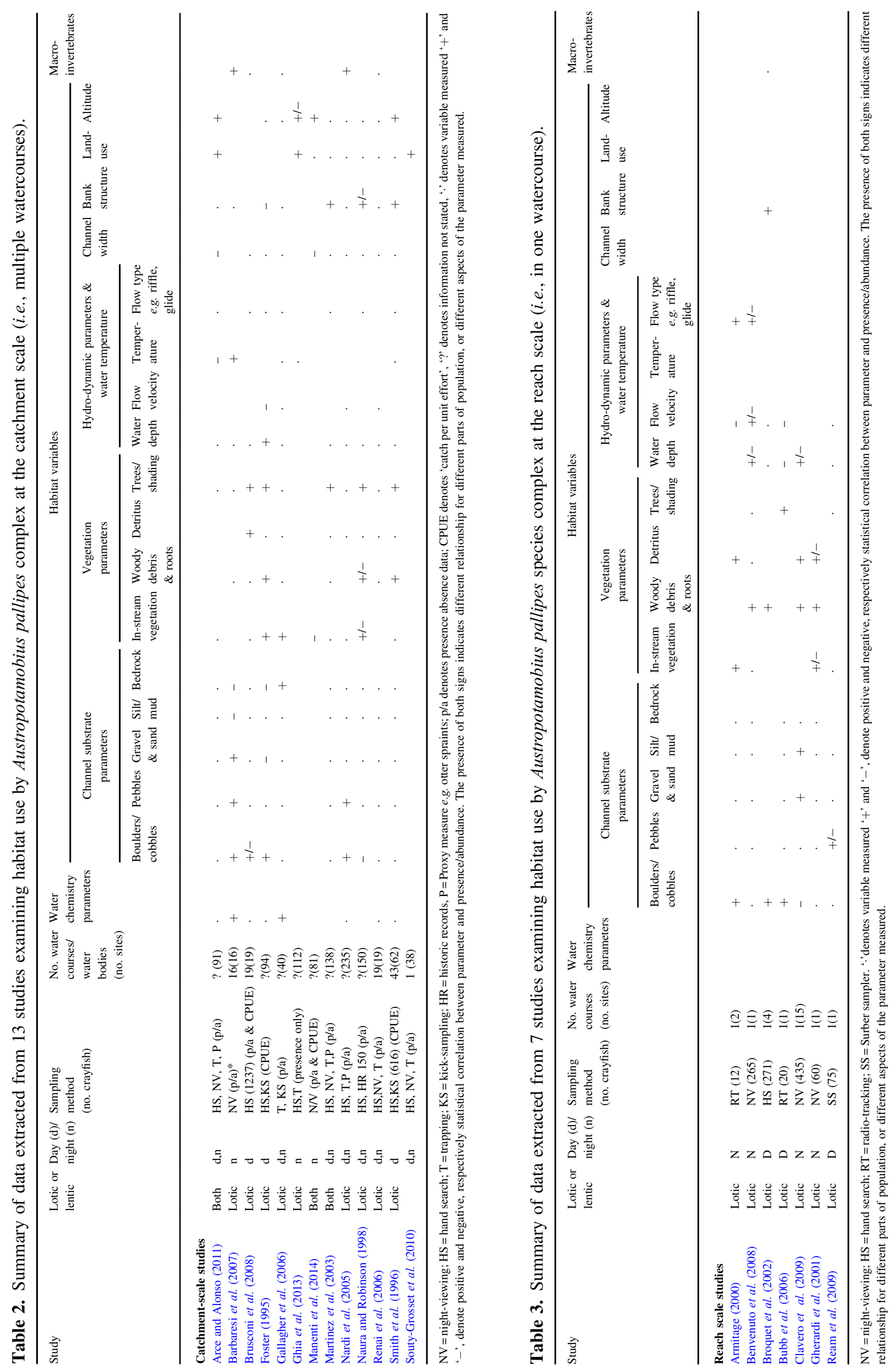




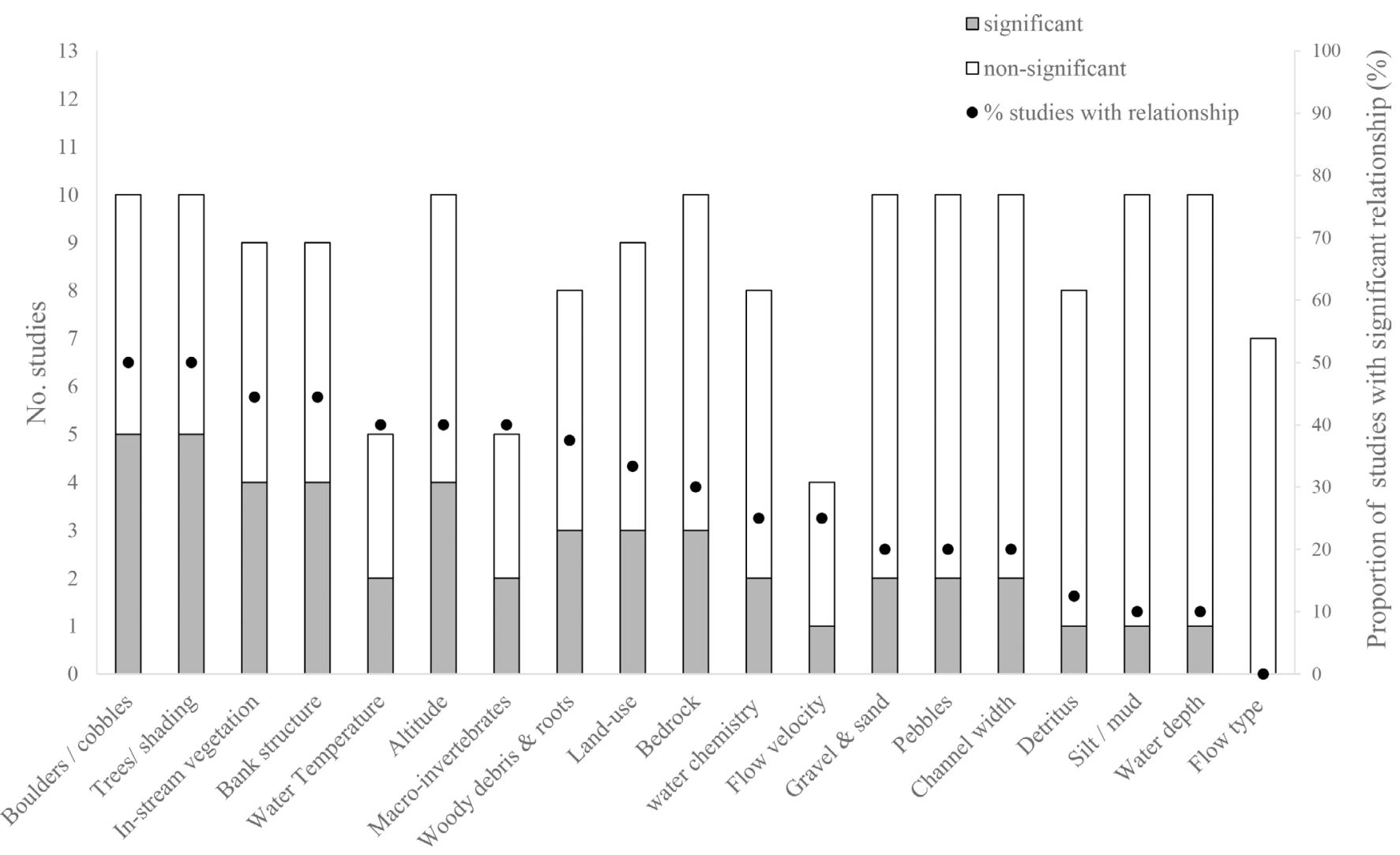

Fig. 1. Number of primary research studies assessing the importance of 19 habitat variables for Austropotamobius pallipes species complex at the catchment scale (in multiple watercourses). Bars indicate the number of studies that addressed each variable, with those showing a significant relationship shaded. Points indicate the percentage for which a significant relationship was found.

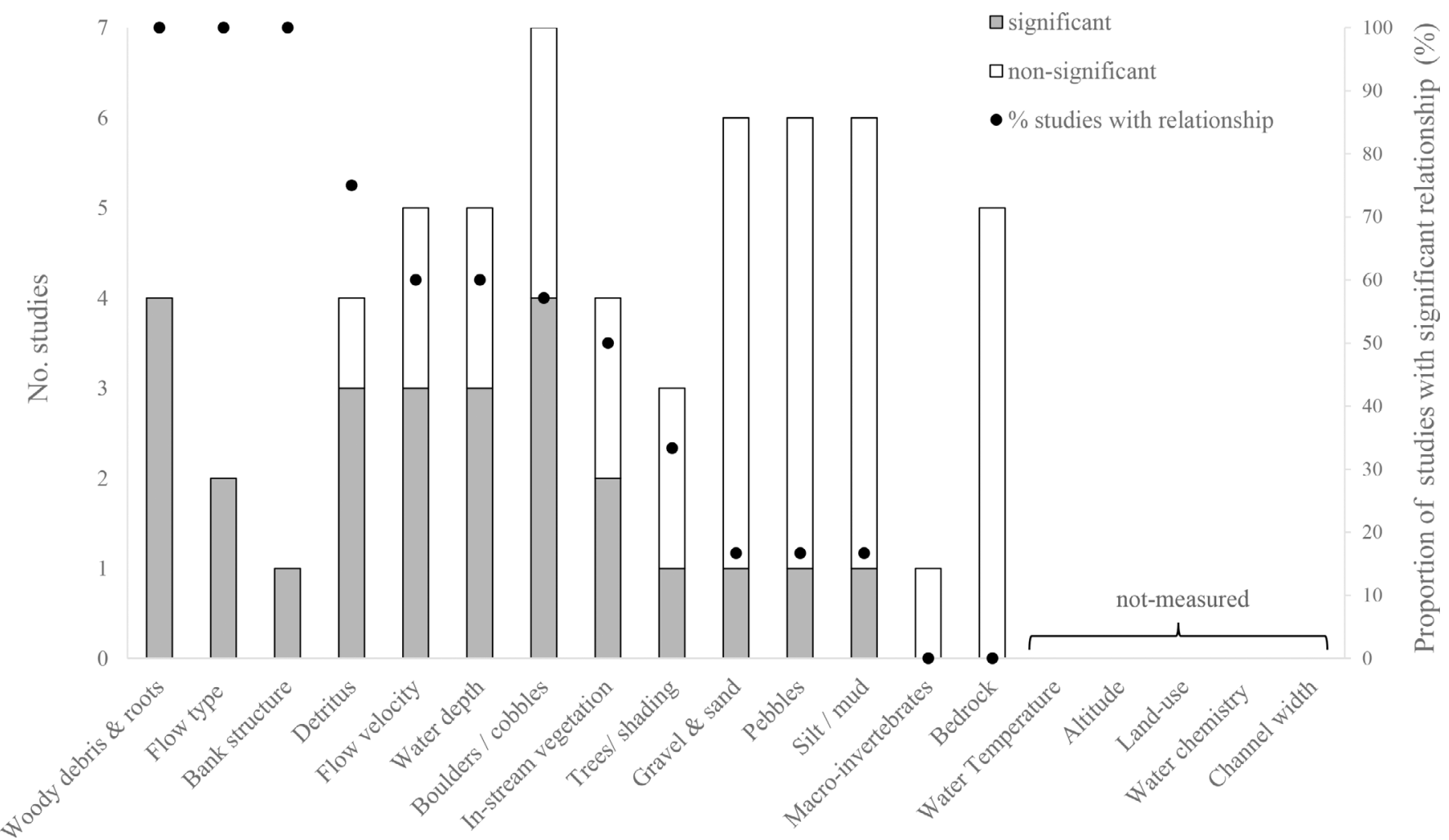

Fig. 2. Number of primary research studies assessing the importance of 19 habitat variables for Austropotamobius pallipes species complex at the reach scale (in one watercourse). Bars indicate the number of studies that addressed each variable, with those showing a significant relationship shaded. Points indicate the percentage for which a significant relationship was found. 
2009). Both studies were conducted at night and therefore indicate habitat use during active foraging periods rather than during the day when crayfish remain in refugia. The preference for finer substrates during foraging may reflect an association between fine particulate and detritus, an important food resource for crayfish, with high nutritional content (Gherardi et al., 2001).

\subsection{Vegetation}

All four vegetation parameters investigated were significant at both the catchment and reach scales, though their relative importance varied with scale. The presence of canopy cover was most important at the catchment scale, with a positive relationship identified in all studies. Woody debris and roots were most important at the reach scale, again always positively associated with crayfish. The positive relationship between detritus and crayfish was more apparent at the reach scale, though was also identified in one catchment scale study. In-stream vegetation, particularly mosses, was generally positively associated with crayfish occurrence (Foster, 1995; Gallagher et al., 2006), although Manenti et al. (2014) found a negative association with periphyton, and Naura and Robinson (1998) with liverworts.

Riparian and in-stream vegetation provide two key functions with regards to crayfish: as a food source, and as physical habitat. Crayfish directly consume macrophytes, allochthonous detritus, periphyton and mosses (though perhaps the fungal and periphyton communities within them) (Brown and Bowler, 1977; Gherardi et al., 2004; Reynolds and O'Keefe, 2005; Gallagher et al., 2006) and moss-covered roots and detritus beds were the most preferred foraging habitats (Gherardi et al., 2001). As an omnivore, A. pallipes also preys on a wide range of invertebrate taxa including Mollusca, Trichoptera and Amphipoda (Reynolds and O'Keefe, 2005) which consume basal resources and transfer energy to higher trophic levels. Therefore, direct consumption of the primary producers as well as the invertebrates associated with them likely underpins the observed positive associations between crayfish and in-stream vegetation, detritus and tree presence. The less expected negative association found with liverworts may reflect covariance between variables as liverworts tend to be found in areas of acidic geology which are chemically less suitable for crayfish (Jay and Holdich, 1981). Trees, in addition to providing leaf inputs, supply cover and shade, thereby likely reducing predation risk and maintaining cool water temperatures which are associated with higher dissolved oxygen concentration. The woody debris and roots associated with trees are important refugia, particularly for juveniles (Benvenuto et al., 2008; Neveu, 2009) and where flow regimes are "flashy" (Smith et al., 1996).

\subsection{Hydrodynamics and water temperature}

Overall, hydrodynamic parameters emerged as less important in crayfish habitat use than vegetation parameters, with $32 \%$ of the potential associations investigated found to be significant compared to $46 \%$ for vegetation variables. Water temperature was significant at the catchment scale (Tab. 2), and flow velocity and type (most commonly defined as pool, glide and riffle mesohabitats) were significant at the reach scale (Tab. 3). In general, crayfish were associated with lower water temperatures, which always co-varied with altitude, indicating that $A$. pallipes tended to occur in higher and cooler sites with populations reported at $1547 \mathrm{~m}$ (Arce and Alonso, 2011), though is generally absent from very high mountains, i.e., occupies a central zone (Nardi et al., 2005; Ghia et al., 2013). It is unclear whether this relationship reflects a true habitat preference among $A$. pallipes or distribution patterns resulting from the spread of invasive crayfish which generally expand their range upstream from the lower reaches of watercourses with the remaining native populations persisting in headwaters (Collas et al., 2007). Three studies, all at the reach scale, reported a negative association with flow rate (Armitage, 2000; Bubb et al., 2006; Benvenuto et al., 2008), and one a negative association with riffles (Benvenuto et al., 2008). Although A. pallipes is largely restricted to running waters, it is generally absent from those with very high flow rates (Foster, 1995). For example, in the headwaters of the River Brugga, Germany, A. pallipes are considered to be limited in their upstream extent by a combination of low water temperatures, high flow velocities (up to $0.6 \mathrm{~ms}^{-1}$ immediately upstream compared to a maximum of $0.43 \mathrm{~ms}^{-1}$ in the colonised stretch) and substrate mobilisation during flood events (Wendler et al., 2015). In a study with co-occurring invasive $P$. leniusculus, $A$. pallipes was found to inhabit slower water, perhaps reflecting a lower tolerance of high velocities (Bubb et al., 2006). Similarly, Clavero et al. (2009) found A. pallipes to preferentially use the deeper, slower water of in-stream pools, with larger crayfish found in the deepest areas, perhaps excluding smaller individuals from this prime foraging habitat. For adult crayfish, which are most vulnerable to terrestrial predators, deeper habitats also offer a reduced risk of predation whereas juveniles may seek shallower habitats to reduce predation from fish (Nyström and Holdich, 2002).

\subsection{Bank structure}

Bank structure was significant at the catchment scale, with a relationship reported in 4 of the 9 studies (44\%) that recorded this variable. A. pallipes was positively associated with nonchannelised banks (Martinez et al., 2003) with a vertical profile (Smith et al., 1996), and negatively associated with sloping banks/beach (Foster, 1995) and poached or reinforced banks (Naura and Robinson, 1998). Only one study considered bank structure at the reach scale and identified undercutting as a key feature which creates refugia readily exploited by crayfish (Broquet et al., 2002). This is particularly important for juveniles and where the abundance of boulder and cobbles substrates is low (Smith et al., 1996).

\subsection{Land-use}

Land-use within a catchment is informative of physical habitat characteristics and potential pressures as the result of human activities. Certain land-uses favour crayfish such as wooded areas (Nardi et al., 2005; Souty-Grosset et al., 2010; Ghia et al., 2013), which provide leaf inputs and habitat complexity as previously discussed. In general, there is a negative relationship between crayfish presence and human 
population/influence (e.g. Nardi et al., 2005) which is likely due to localised human mediated introductions of invasive crayfish, and wider degradation of watercourses making them less suitable for A. pallipes (Fureder et al., 2002). Similar findings have also been reported for the closely related species A. torrentium (Chucholl and Schrimpf, 2016).

\subsection{Water chemistry}

The analysis included only those studies which measured the importance of physical habitat, and excluded studies whose sole focus was water chemistry which is reviewed elsewhere (Trouilhe et al., 2007; Haddaway et al., 2015). However, 8 of the catchment-scale studies analysed included chemistry as well as physical habitat. For the 2 studies that found water chemistry to be a predictor of occurrence, the concentration of calcium was particularly important with a positive relationship between crayfish occurrence and concentration (Gallagher et al., 2006; Barbaresi et al., 2007), as has been previously highlighted (e.g. Trouilhe et al., 2007; Favaro et al., 2010). Crayfish have a strong dependence on calcium for maintenance of the exoskeleton (Greenaway, 1985) and generally do not persist in locations where calcium concentration is below $5 \mathrm{mg} \mathrm{L}^{-1}$ (Jay and Holdich, 1981; Haddaway et al., 2015). Although 6 of the studies did not identify a relationship with water chemistry parameters, this likely reflects the lack of variation in such parameters over the scales studied, i.e., within catchment, rather than importance more generally. Suitable water chemistry is known to be a crucial determinant of whether crayfish will be present in a catchment or not (Jay and Holdich, 1981), but is clearly less indicative of occurrence over smaller scales.

\subsection{Macro-invertebrates}

Macro-invertebrates are an important food source for $A$. pallipes (Reynolds and O'Keefe, 2005), but in the context of the studies examined, the diversity and abundances of macro-invertebrates were used to calculate indices representative of water quality. In two of the five studies that recorded macro-invertebrates, crayfish presence was positively associated with greater index scores, inferring that $A$. pallipes prefer sites with better water quality. A recent study considered the potential to use Ephemeropteran communities as bioindicators for the selection of restocking sites, with some indication that Ephemeroptera diversity was positively associated with restocking success (Jandry et al., 2014). Conversely, the utility of $A$. pallipes as a bioindicator of water quality has been much debated with some authors questioning the reliability of this approach (Fureder and Reynolds, 2003). A. pallipes can persist in watercourses of sub-optimal water quality (Broquet et al., 2002; Demers and Reynolds, 2002) and there is also evidence that it can survive low oxygen, at least for short periods. In a summer study, oxygen concentrations dropped as low as $4.93 \mathrm{mg} \mathrm{L}^{-1}$ with no apparent detriment to the resident crayfish (Trouilhe et al., 2007).

\subsection{Habitat partitioning}

The use of presence-absence crayfish data precluded consideration of potential variation in habitat use due to crayfish size class or sex in the majority of studies. Where this was investigated (6 studies), clear patterns of habitat partitioning were apparent. For example, Clavero et al. (2009) identified a preference for deeper habitat among adult size classes that was lacking in juveniles. Two further studies similarly found that juveniles made greater use of the shallow channel margins than adults and were presumed to be exploiting refugia within exposed roots (Smith et al., 1996; Benvenuto et al., 2008). Ream et al. (2009) found that small crayfish $(1+)$ tended to use smaller pebble substrates during daytime refuge. Variations in habitat use due to different foraging patterns between the sexes were highlighted in another study whereby males occupied mostly detritus and females on moss covered roots (Gherardi et al., 2001). Such patterns may be mediated by actual variations in habitat preferences, through intra-specific competition whereby larger, male crayfish exclude younger year classes or subordinate females from prime foraging areas or refugia (Gherardi et al., 2001), or through habitat-specific and size selective predation (Garvey et al., 2003).

\section{Conclusion and recommendations}

Studies examining habitat use of $A$. pallipes comprised two clear groups: those incorporating habitat variables measured in several watercourses and related to $A$. pallipes, usually by presence absence data (catchment scale), and those examining microhabitat use within just one watercourse (reach scale). Vegetation parameters were most commonly identified as important for $A$. pallipes, in particular, trees/ shading at the catchment scale and woody debris and roots at the reach scale were positively associated with crayfish. Channel substrate parameters were second most important, with larger substrates such as cobbles and boulders positively associated with crayfish presence, though finer substrates such as silt were used during foraging.

The reviewed studies originated from four western European countries and therefore addressed populations over a wide geographical range which is important because species may vary in their environmental tolerances, and therefore habitat requirements, through genetic and phenotypic plasticity (e.g. Ayrinhac et al., 2004; Haddaway et al., 2012). A strong bias towards the study of crayfish from lotic rather than lentic systems was apparent in the literature retrieved. While most wild populations of $A$. pallipes occur in lotic environments, the majority of suitable ark sites are likely to be lentic water bodies due to their low connectivity and associated low risk of invasion (Peay, 2009; Whitehouse et al., 2009).

Based on the strength of findings, we recommended that Ark sites incorporate habitat features that both provide refugia during daytime (e.g. boulders, undercut banks, exposed roots), as well as enhance night-time foraging (e.g. overhanging trees, ample detritus, silt beds and submerged vegetation). Clear patterns were lacking for many of the variables examined, in part due to habitat partitioning among size classes and sexes. To reduce intra-specific competition in Ark sites it is particularly important to provide ample heterogeneous habitat with a range of features beneficial to A. pallipes, thereby facilitating habitat partitioning.

Acknowledgements. This work was funded by NERC casestudentship with project partners Lafarge Tarmac to PJR. 


\section{References}

Alderman DJ, Holdich D, Reeve I. 1990. Signal crayfish as vectors in crayfish plague in Britain. Aquaculture 86: 3-6.

Arce J, Alonso F. 2011. Factors related to the presence of the Austropotamobius pallipes (Lereboullet, 1858) species complex in calcareous mountin rivers in central Spain. Knowl Manag Aquat Ecosyst 401: 25.

Armitage V. 2000. Observations of radio tracked crayfish (Austropotamobius pallipes) in a northern British river. In: Rogers D, Brickland J, eds. Crayfish Conference Leeds. Leeds: Environment Agency, pp. 63-69.

Ayrinhac A, Debat V, Gibert P, et al. 2004. Cold adaptation in geographical populations of Drosophila melanogaster: phenotypic plasticity is more important than genetic variability. Funct Ecol 18: 700-706.

Barbaresi S, Gherardi F. 2001. Daily activity of the white-clawed crayfish, Austropotamobius pallipes (Lereboullet): a comparison between field and laboratory studies. J Nat Hist 35: 1861-1871.

Barbaresi S, Cannicci S, Vannini M, Fratini S. 2007. Environmental correlates of two macro-decapods distribution in Central Italy: multi-dimensional ecological knowledge as a tool for conservation of endangered species. Biol Conserv 136: 431-441.

Benvenuto C, Gherardi F, Ilheu M. 2008. Microhabitat use by the white-clawed crayfish in a Tuscan stream. J Nat Hist 42: 21-33.

Broquet T, Thibault M, Neveu A. 2002. Distribution and habitat requirements of the white-clawed crayfish, Austropotamobius pallipes, in a stream from the Pays de Loire region, France: an experimental and descriptive study. Bull Fr Pêche Piscic 367: 717-728.

Brown DJ, Bowler K. 1977. A population study of the British Freshwater Crayfish, Austropotamobius pallipes (Lereboullet). Freshw Crayfish 3: 16.

Brusconi S, Bertocchi S, Renai B, Scalici M, Souty-Grosset C, Gherardi F. 2008. Conserving indigenous crayfish: stock assessment and habitat requirements in the threatened Austropotamobius italicus. Aquat Conserv 18: 1227-1239.

Bubb DH, Thom TJ, Lucas MC. 2006. Movement, dispersal and refuge use of co-occurring introduced and native crayfish. Freshw Biol 51: 1359-1368.

Buglife. 2009. Criteria for selection of Ark sites for white-clawed crayfish - MS EXCEL tool (v.1, April '09). Peterborough: Buglife - The Invertebrate Conservation Trust. Available at: www.buglife.org.uk.

Chiesa S, Scalici M, Negrini R, Gibertini G, Marzano FN. 2011. Finescale genetic structure, phylogeny and systematics of threatened crayfish species complex. Mol Phylogenet Evol 61: 1-11.

Chucholl C, Schrimpf A. 2016. The decline of endangered stone crayfish (Austropotamobius torrentium) in southern Germany is related to the spread of invasive alien species and land-use change. Aquat Conserv Mar Freshw Ecosyst 26 (1): 44-56.

Clavero M, Benejam L, Seglar A. 2009. Microhabitat use by foraging white-clawed crayfish (Austropotamobius pallipes) in stream pools in the NE Iberian Peninsula. Ecol Res 24: 771-779.

Collas M, Julien C, Monnier D. 2007. La situation des écrevisses en France résultats des enquêtes nationales réalisées entre 1977 et 2006 par le conseil supérieur de la pêche. Bull Fr Pêche Piscic 386: $1-38$.

Demers A, Reynolds JD. 2002. A survey of the white-clawed crayfish, Austropotamobius pallipes (Lereboullet), and of water quality in two catchments of eastern Ireland. Bull Fr Pêche Piscic 367: 729-740.

Favaro L, Tirelli T, Pessani D. 2010. The role of water chemistry in the distribution of Austropotamobius pallipes (Crustacea Decapoda Astacidae) in Piedmont (Italy). C R Biol 333: 68-75.
Foster J. 1995. Factors influencing the distribution and abundance of crayfish Austropotamobius pallipes in Wales and the Marches. Freshw Crayfish 8: 78-93.

Fratini S, Zaccara S, Barbaresi S, et al. 2005. Phylogeography of the threatened crayfish (genus Austropotamobius) in Italy: implications for its taxonomy and conservation. Heredity 94: 108-118.

Fureder L, Reynolds JD. 2003. Is Austropotamobius pallipes a good bioindicator? Bull Fr Pêche Piscic 370-371: 157-163.

Fureder L, Oberkofler B, Hanel R, Machino Y. 2002. Freshwater crayfish in South Tyrol (Italy): distribution and protection measures of endangered Austropotamobius pallipes. Bull Fr Pêche Piscic 370-371: 651-662.

Gallagher MB, Dick JTA, Elwood RW. 2006. Riverine habitat requirements of the white-clawed crayfish, Austropotamobius pallipes. Biol Environ 106B: 1-8.

Garvey JE, Rettig JE, Stein RA, Lodge DM, Klosiewski SP. 2003. Scale-dependent associations among fish predation, littoral habitat, and distributions of crayfish species. Ecology 84: 3339-3348.

Gherardi F, Cioni A. 2004. Agonism and interference competition in freshwater decapods. Behaviour 141: 1297-1324.

Gherardi F, Acquistapace P, Santini G. 2001. Foraging by a threatened species - the white-clawed crayfish, Austropotamobius pallipes. Arch Hydrobiol 152: 339-351.

Gherardi F, Smietana P, Laurent P. 2002. Interactions between nonindigenous and indigenous crayfish species. Bull Fr Pêche Piscic 367: 899-907.

Gherardi F, Acquistapace P, Santini G. 2004. Food selection in freshwater omnivores: a case study of crayfish Austropotamobius pallipes. Arch Hydrobiol 159: 357-376.

Ghia D, Fea G, Sacchi R, et al. 2013. Modelling environmental niche for the endangered crayfish Austropotamobius pallipes complex in Northern and Central Italy. Freshw Crayfish 19: 189-195.

Gil-Sanchez JM, Alba-Tercedor J. 2002. Ecology of the native and introduced crayfishes Austropotamobius pallipes and Procambarus clarkii in southern Spain and implications for conservation of the native species. Biol Conserv 105: 75-80.

Grandjean F, Souty-Grosset C. 2000. Mitochondrial DNA variation and population genetic structure of the white-clawed crayfish, Austropotamobius pallipes pallipes. Conserv Genet 1: 309-319.

Grandjean F, Frelon-Raimond M, Souty-Grosset C. 2002. Compilation of molecular data for the phylogeny of the genus Austropotamobius: one species or several? Bull Fr Pêche Piscic 671-680.

Greenaway P. 1985. Calcium balance and moulting in the Crustacea. Biol Rev 60: 425-454.

Haddaway N, Mortimer R, Christmas M, Dunn A. 2015. Water chemistry and endangered white-clawed Crayfish: a literature review and field study of water chemistry association in Austropotamobius pallipes. Knowl Manag Aquat Ecosyst 416: 01.

Haddaway NR, Mortimer RJ, Christmas M, Grahame JW, Dunn AM. 2012. Morphological diversity and phenotypic plasticity in the threatened British white-clawed crayfish (Austropotamobius pallipes). Aquat Conserv 22: 220-231.

Hogger JB. 1986. Aspects of the introduction of signal crayfish Pacifastacus leniusculus (Dana), into the southern United Kingdom. 1. Growth and survival. Aquaculture 58: 27-44.

Holdich D, Rogers D. 2000. Habitat requirements of the white-clawed crayfish, Austropotamobius pallipes. In: Rogers D, Brickland J, eds. Crayfish Conference Leeds.Leeds: Environment Agency, pp.97-106.

Holdich D, Sibley PJ, Peay S. 2004. The white-clawed crayfish - a decade on. Br Wildl 15: 11.

Holdich DM. 2003a. Crayfish in Europe - an overview of taxonomy, legislation, distribution, and crayfish plague outbreaks. In: Holdich D, Sibley P, eds. Management \& Conservation of Crayfish. Nottingham: Environment Agency, pp. 15-34. 
Holdich DM. 2003b. Ecology of the White-clawed Crayfish. Conserving Natura 2000 Rivers Ecology Series No. 1. Peterborough: English Nature.

Holdich DM, Gherardi F. 1999. Native and alien crayfish in Europe: an introduction. In: Crayfish in Europe as Alien Species 11, pp. 3-9.

Holdich DM, Reeve ID. 1991. Distribution of freshwater crayfish in the British Isles, with particular reference to crayfish plague, alien introductions and water-quality. Aquat Conserv 1: 139-158.

Huber MGJ, Schubart CD. 2005. Distribution and reproductive biology of Austropotamobius torrentium in Bavaria and documentation of a contact zone with the alien crayfish Pacifastacus leniusculus. Bull Fr Pêche Piscic 376-377: 759-776.

IUCN. 2012. IUCN Guidelines for Reintroductions and Other Conservation Translocations.

Jandry J, Brulin M, Parinet B, Grandjean F. 2014. Ephemeroptera communities as bioindicators of the suitability of headwater streams for restocking with white-clawed crayfish, Austropotamobius pallipes. Ecol Indicators 46: 560-565.

Jay D, Holdich DM. 1981. The distribution of the crayfish, Austropotamobius pallipes, in British waters. Freshw Biol 11: 121-129.

Kemp E, Birkinshaw N, Peay S, Hiley PD. 2003. Reintroducing the White-clawed Crayfish Austropotamobius pallipes. Conserving Natura 2000 Rivers Conservation Techniques Series No. 1. Peterborough: English Nature.

Kindemba V, Whitehouse A. 2009. Using GIS to identify and prioritize regional ark sites for white-clawed crayfish: aggregate and mineral extraction sites in South-west England. In: Brickland J, Holdich D, Imhoff E, eds. Proceedings of a conference held on 25th March 2009 in Leeds, UK, pp. 71-84.

Lodge DM, Hill AM. 1994. Factors governing species composition, population size, and productivity of cool-water crayfishes. Nord $J$ Freshwat Res 69: 111-136.

Machino Y, Füreder L. 2005. How to find a stone crayfish Austropotamobius torrentium (Schrank, 1803): a biogeographic study in Europe. Bull Fr Pêche Piscic 376-377: 507-577.

Manenti R, Bonelli M, Scaccini D, Binda A, Zugnoni A. 2014. Austropotamobius pallipes reduction vs. Procambarus clarkii spreading: management implications. J Nat Conserv 22: 586-591.

Martinez R, Rico E, Alonso F. 2003. Characterisation of Austropotamobius italicus (Faxon,1914) populations in a Central Spain area. Bull Fr Pêche Piscic 370-371: 43-56.

Nardi P, Bernini F, Bo T, et al. 2005. Status of Austropotamobius pallipes complex in the watercourses of the Alessandria province (NW Italy). Bull Fr Pêche Piscic 376-377: 585-598.

Naura M, Robinson M. 1998. Principles of using River Habitat Survey to predict the distribution of aquatic species: an example applied to the native white-clawed crayfish Austropotamobius pallipes. Aquat Conserv 8: 515-527.

Neveu A. 2009. A functional approach to patch suitability using biomass dynamics: application to a residual population of the white-clawed crayfish. Fund Appl Limnol 175: 185-202.

Nyström P, Holdich DM. 2002. Ecology. In: Holdich D, ed. Biology of Freshwater Crayfish. Oxford: Blackwell Science, pp. 192-235.

Olsson K, Nystrom P. 2009. Non-interactive effects of habitat complexity and adult crayfish on survival and growth of juvenile crayfish (Pacifastacus leniusculus). Freshw Biol 54: 35-46.
Osborne PE, Seddon PJ. 2012. Selecting suitable habitats for reintroductions: variation, change and the role of species distribution modelling. In: Ewen J, Armstrong D, Parker K, Seddon P, eds. Reintroduction Biology: Integrating Science and Management. Wiley-Blackwell, pp. 73-104.

Peay S. 2009. Selection criteria for "ark sites" for the white-clawed crayfish. In: Brickland J, Holdich D, Imhoff I, eds. Proceedings of a conference held on 25th March 2009 in Leeds, UK, pp. 63-70.

Ream H, Bubb D, Lucas M. 2009. Microhabitat use and recolonisation of in white-clawed crayfish: application to conservation. In: Brickland J, Holdich D, Imhoff E, eds. Proceedings of a conference held on 25th March 2009 in Leeds, UK, pp. 95-98.

Renai B, Bertocchi S, Brusconi S, et al. 2006. Ecological characterisation of streams in Tuscany (Italy) for the management of the threatened crayfish Austropotamobius pallipes complex. Bull Fr Pêche Piscic 380-381: 1095-1113.

Reynolds J, O'Keefe C. 2005. Dietary patterns in stream-and lakedwelling populations of Austropotamobius pallipes. Bull Fr Pêche Piscic 376: 715-730.

Schulz R, Stucki T, Souty-Grosset C. 2002. Management: reintroductions and restocking. Bull Fr Pêche Piscic 367: 917-922.

Seddon PJ, Armstrong DP, Maloney RF. 2007. Developing the science of reintroduction biology. Conserv Biol 21: 303-312.

Smith GRT, Learner MA, Slater FM, Foster J. 1996. Habitat features important for the conservation of the native crayfish Austropotamobius pallipes in Britain. Biol Conserv 75: 239-246.

Souty-Grosset C, Reynolds J. 2009. Current ideas on methodological approaches in European crayfish conservation and restocking procedures. Knowl Manag Aquat Ecosyst 394-395: 01.

Souty-Grosset C, Holdich D, Noel P, Reynolds J, Haffner P. 2006. Atlas of Crayfish in Europe. Paris: Museum National d'Histoire Naturelle (Patrimoines naturels; 64), $187 \mathrm{p}$.

Souty-Grosset C, Hardy V, Raimond R, Ollivier L. 2010. Land use in headwaters and the distribution of native whiteclawed crayfish, Austropotamobius pallipes (Lereboullet), in a stream from the Poitou-Charentes region, France. Freshw Crayfish 17: 129-134.

Streissl F, Hödl W. 2002. Habitat and shelter requirements of the stone crayfish, Austropotamobius torrentium Schrank. Hydrobiologia 477 (1): 195-199.

Sutherland WJ. 2008. The Conservation Handbook: Research, Management and Policy. Oxford: John Wiley \& Sons, 296 p.

Trouilhe MC, Souty-Grosset C, Grandjean F, Parinet B. 2007. Physical and chemical water requirements of the white-clawed crayfish (Austropotamobius pallipes) in western France. Aquat Conserv 17: 520-538.

Watson E, Rogers D. 2003. A model for the selection of refugia for white-clawed crayfish. In: Holdich D, Sibley P, eds. Management $\&$ Conservation of Crayfish. Nottingham: Environment Agency, pp. 121-126.

Wendler F, Biss R, Chucholl C. 2015. Population ecology of endangered white-clawed crayfish (Austropotamobius pallipes s. str.) in a small rhithral river in Germany. Knowl Manag Aquat Ecosyst 416: 24.

Whitehouse AT, Peay S, Kindemba V. 2009. Ark sites for whiteclawed crayfish - guidance for the aggregates industry. Peterborough: Buglife - The Invertebrate Conservation Trust. 